術後30年目に腋窩リンパ節再発をきたした乳癌の 1 例

\begin{tabular}{|c|c|c|c|c|c|c|c|c|c|}
\hline & & & 海大 & 学東 & 京病院 & 浣外 & & & \\
\hline 太田 & 正 & 敬 & 杉 & 原 & & 隆 & 向 & 井 & 正 \\
\hline 左々木 & 哲 & $=$ & 白 & 石 & 幸治 & & & & \\
\hline & & & 同 & 第 & 2 外柇 & & & & \\
\hline 田 & 優 & 子 & 奧 & 村 & & 輝 & 徳 & 田 & \\
\hline 保斗 & 光 & 博 & 田 & 島 & 知 & 郎 & $\equiv$ & 富 & 利 \\
\hline
\end{tabular}

乳癌の手術後30年目に再発をきたした 1 例を経験した，症例は73歳，女性，1960年 4 月，43歳時に右乳癌にて非定型的乳房切断術を受计た，1990年 2 月に右腋简腫嗐を主訴 に来院した。来院時， $5 \times 4 \mathrm{~cm}$ の可動性のない弾性硬の尰瘦を触知し，血清 NCC-ST-439

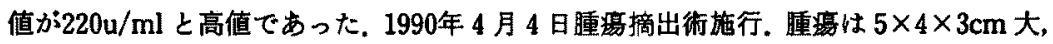
充実性で，組織学的には腺癌よりなり，リンパ節組織，乳腺組織仙認められず，免废組 織化学的に $\alpha_{1}$ ・ラクトアルブミン, DF-3，115D8およびNCC-ST-439が陽性であった。さ

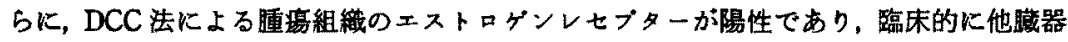
に原発巣と考克られる病変は認められなかったことから乳癌の腋简リンハ節転移と考兄

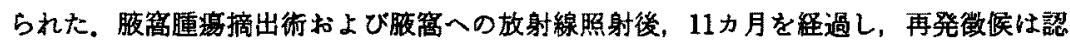
められず，血清 NCC-ST-439值は $2.7 \mathrm{u} / \mathrm{ml}$ と正常範井内にある。

卖引用語：乳癌, 転移, 再発

\section{はじめに}

乳癌術後の再発は術挠 1 ないし 2 年目にもっとる多 くみられ，20年以上を経ての再発注0.1\%にすぎな い. 30年前に乳䍄の診断で乳房切断術を受け，今回， 腋窩リンパ節再発をきたしたと考えられる症例を経験 したので若干の文献的考察を加え報告する。

$$
\text { 症例 }
$$

患者：73歳，女性。妊娠・分婏歴なし，閉経47歳時。 主訴：右腋窗睡瘤。

家族歷：特記すへきことなし、

既往歴：43歳時，右乳癌にて非定型的乳房切断術。

現病歴：1990年 2 月頃から，右前腕尺側の知覚低下 を覚えるよらになり，右腋䔰腫癌に気付き来院した。

入院帱現症：体格は中等度，栄羡状態は良好，賓血， 黄疸を認めず，発熱もみられなかった，右腋骷皮冨に

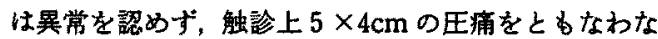
い表面平滑，境界不鮮明で可動性に乏しい弾性硬の腫 瘤を触知した。

1991年6月26日受付 1991年12月26日採用

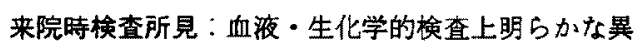
常值は認めなかった。腫場マーカーは, NCC-ST-439か; $220 \mathrm{u} / \mathrm{ml}$ と高值を示し, CEA, CA15-3は正常䇢囲内で あった.

超音波所見：右腋窝部の重㿔は超音波検查上, 境界 明瞕で比較的均一な内部ニコー有するやや hypoechoicな充実珄腫瘤であった。なお，腹部超音波倹㚗で はとくに異常所見は認められなかった（図 1 ）。

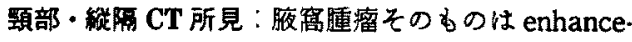
ment に乏しいlow density area として措出された. 頸部および綎隔内には明かな異常所見は認められな かった。

血管造影所見：右上肢軤脈造影では，腋窝静脈は完 全に閉塞されていた(图 2)。同時に施行した動脈造影 では，腋简動脈本幹には encasementは㒛められな かったが，その近傍にわずかな血管新生像が霍察され た.

手術所見：1990年 4月 4 日,腫煬摘出術を施行した。 腫煬は腋菑静眽をまき迈み、これを完全に閉塞させ，

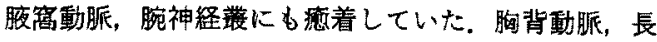




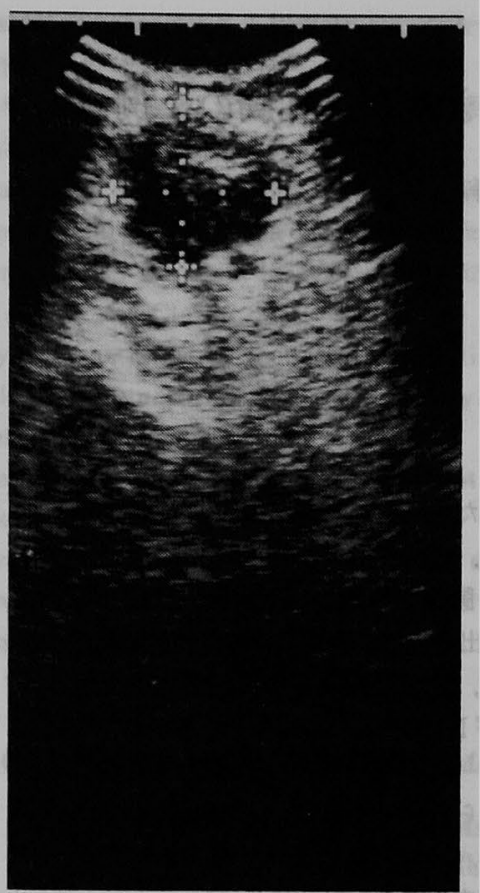

図 1 超音波検查所見：右腋窝部に比較的に境界明瞭 な内部エコーを有する hypoechoicな solid mass を認める。

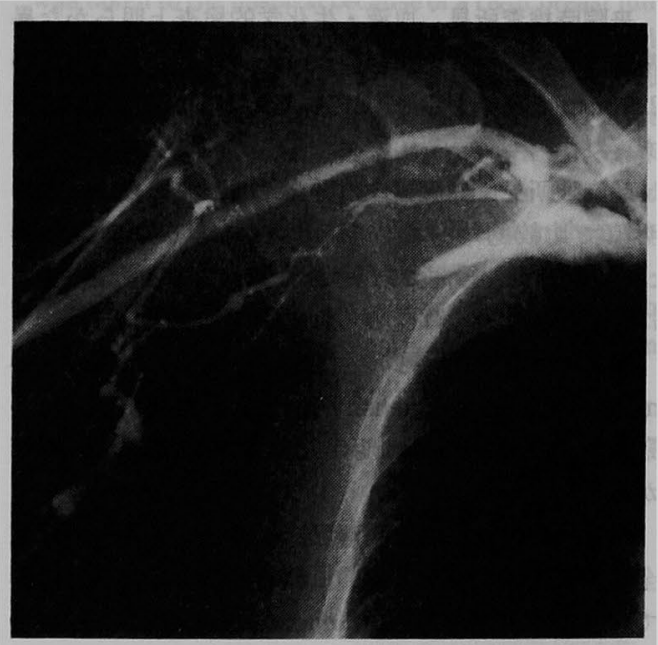

图 2 静脈造影所見：右腋窩静脈の完全閉塞を認め る.

胸神経も腫場に巻き込をれこれらの切断を余儀なく された。

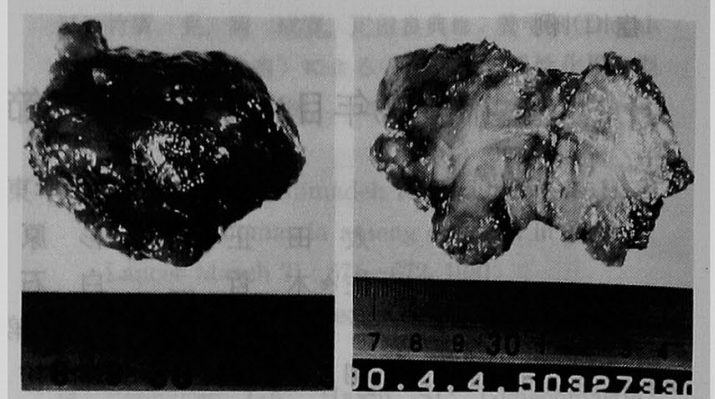

図 3 標出標本およびその割面像：腫瘍は充実性で大 きさは $5 \times 4 \times 3 \mathrm{~cm}$ である。

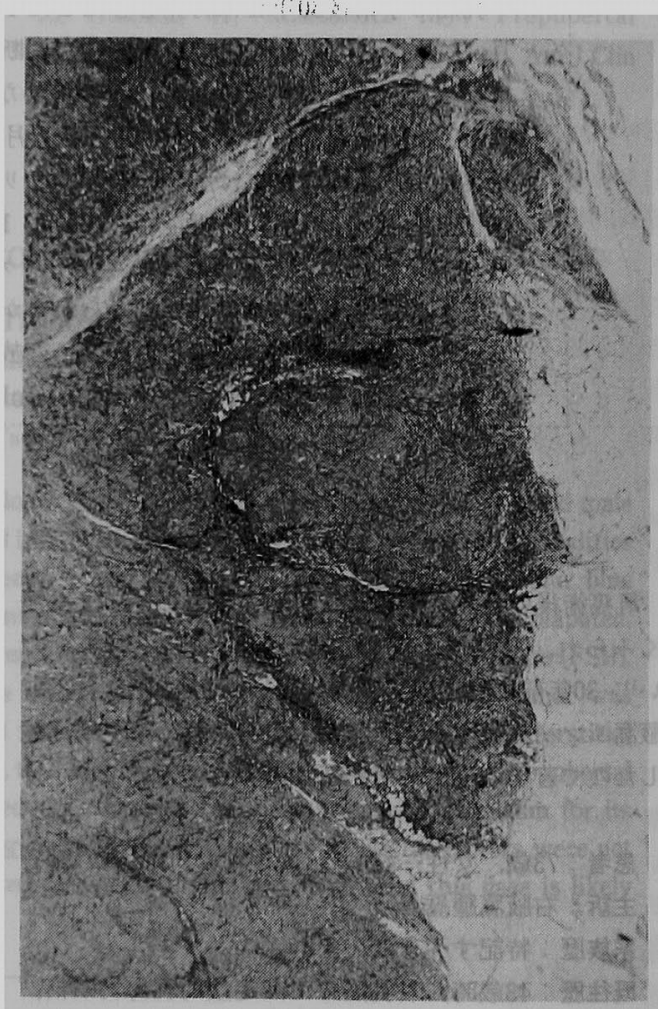

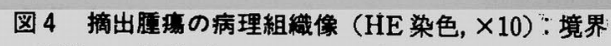
明膫で，尰湯周辺にリンパ球が認められる。

$+x$

切除標本所見：摘出腫瘍は $5 \times 4 \times 3 \mathrm{~cm}$ 大でその 割面は白色を呈し, 数条の中隔形成を示す充実性の尰 湯であった（図3）.

病理組織学的所見：HE 染色では，腫瘍は境界明瞭 で solid tubularな増殖形態を示し，その境界付近には リンハ球が散見されたか，リンパ節の構造は残存して 
いなかった。なた正常な乳腺組織も認められなからた (図 4).

抗 $\alpha_{1}$-ラクトアルプミン抗体 (DAKO 社), 抗 DF-3 抗体 (トーレ・フジハイオニクス社), 抗115D8抗体 （トーレ・フジハイオニクス社）および抗 NCC-ST-439 抗体 (日本化薬) 1 次抗体に用い，2 次抗体として ヘルオキシダーゼ標識山羊抗マウスIgG抗体（F $\left.\left(a b^{\prime}\right)_{2}\right)$ を接触させて，3，3'-diaminobenzidine により 発色させた醭素抗体間接法ではいずれす陽性を示した (图 5A, B, C, D).

また DCC 法による腫湯組織のエストロゲンレセブ ターは, $412 \mathrm{fmol} / \mathrm{mg}$ と陽性であった。

以上より乳癌のリンバ節転移と診断した。
術後経過：術後, adjuvant therapy として腋简に ${ }^{60} \mathrm{Co}$ を計 $45 \mathrm{~Gy}$ 照射した。畽瘍摘出後11カ月を経過し た現在，再発は認められていない，因みに術前高値を 示していた血清 NCC-ST-439值す術後11カ月目の現 時点で $2.7 \mathrm{u} / \mathrm{ml}$ と正常範囲内に復している。

flow cytometry : 摘出腫瘍を 1 から $2 \mathrm{~mm}$ 大に細切 し, trypsin で処理して, Nylon mesh で濾過したのち propidium iodide で染色し，再び Nylon mesh を通し て FACScan (Becton Dikinson 社) にかけた. DNA 解析には SFIT systemを用いた. DNA index は 1.5 で, S 期細胞が21\%を占めた。ヒストグラムはnondiploid pattern を呈した（图6).

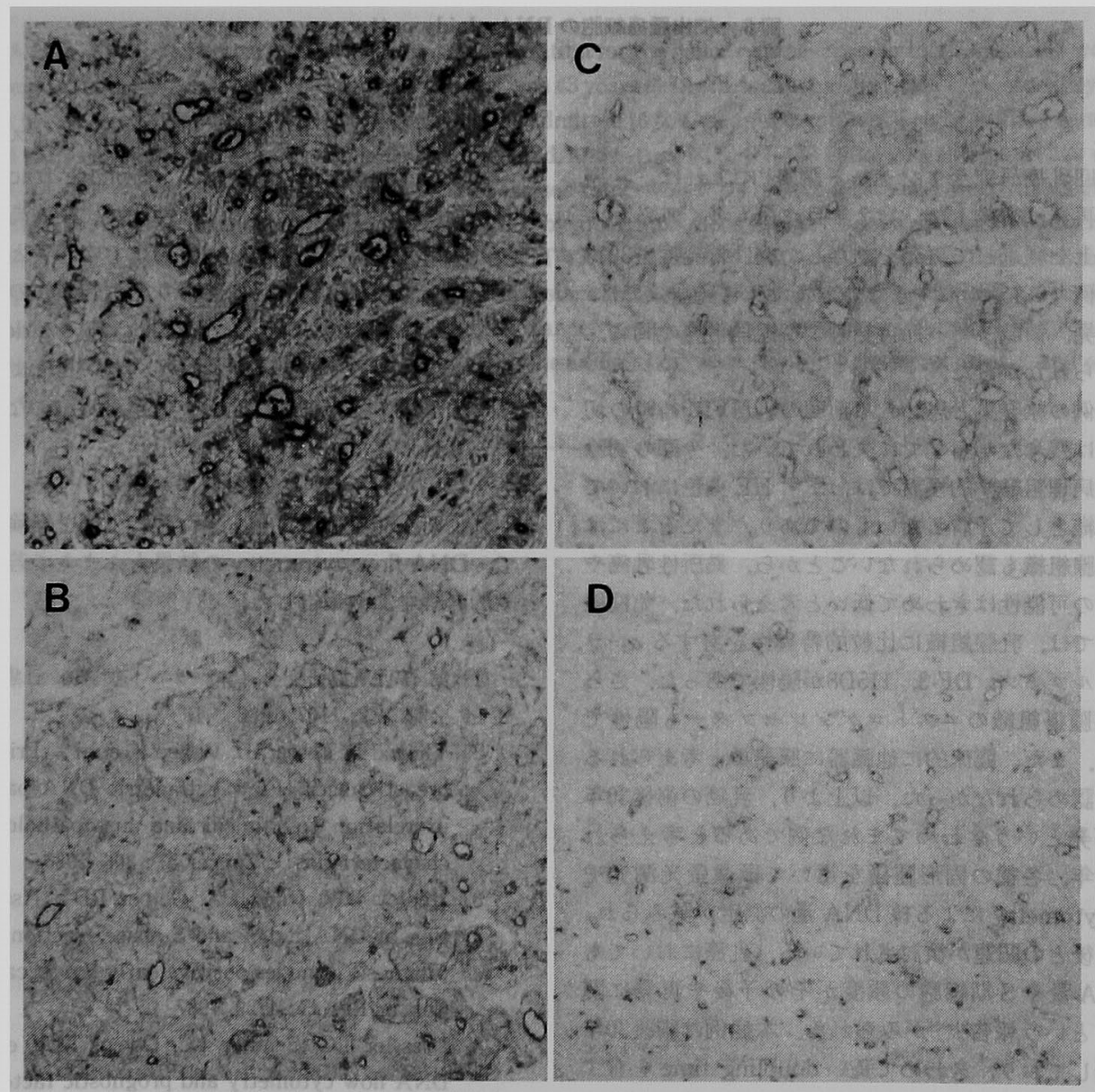

图 5 醇秦抗体法による病理組織像（A： $\alpha_{1}$ ラクトフルブミン, $\times 20, \mathrm{~B}: \mathrm{DF}-3, \times 20$, C: 115 D8, $\times 20$, D : NCC-ST $-439, \times 20)$ 


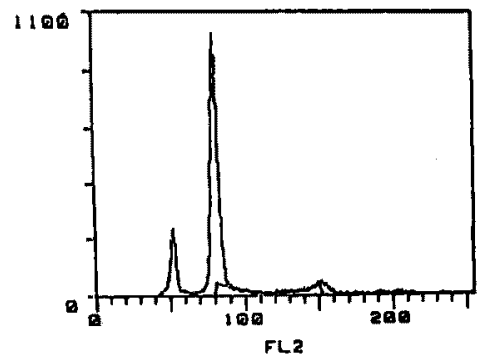

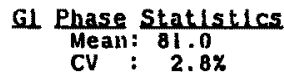
Mean: 81.0
CV : $2.8 \%$
Peak Relatlonshles (Gl/Reference)

Ratlo of Means: 1.5

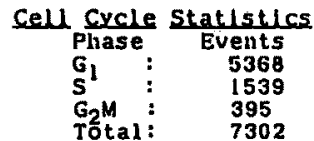

$$
\begin{gathered}
\text { Percent } \\
74 \\
21 \\
5 \\
100
\end{gathered}
$$

SFIT

图 6 筒出腯息細胞の DNA ploidy pattern

\section{考察}

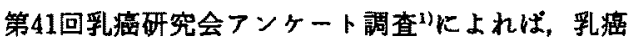
術後の再癹は術後 1 ないし 2 年目に最る多くみられ, 20年以上を経過して再発をきたした例は再発症例3013 例中 4 例 $(0.1 \%)$ にすぎない。文た，再発型式では， 局所再発，領域リンバ節再発战よび遠隔再発の間に，

差はみららなかった。

本庭例の原発巣と思われる前回の乳房切断街時の切 除骠本は残念ながらすでに失われていた，今回の切除 標本の病理組織学的検討では，ます HE染色に拈いて 䄻癌組織として矛盾しないるのであり，またそこには 正常乳腺組織認められないことから，異所性乳癌や 副乳癌の可能性はきわめて低いと考古られた，免疫組 織化学では，乳腺組䅧に比較的特異性を有する $\alpha_{1}$-ラ クトアルブミン, DF-3，115D8が陽性であった，さら に摘出重昜組織のエストロダンレセブターす陽性で

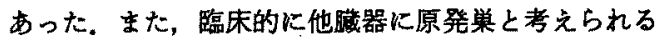
病変は諗められなかった. 以上より，乳癌の術後30年 目の再発といらきわめてまれな例であると考えられ た. 近年, 各種の固形腫場を用いて顕滥光測光や flow cytometry による核 DNA 量の測定が試みられ， その予後との成連が検討されている、乳癌においても 核 DNA 量やS 期細胞の頻度がその予後や再発に関 倸するという報告2) 6)がみられる．本症例は術後30年 を経過してお゙り，きわめて長い doubling timeを有す る可能性があると思われた。 そこで摘出乳癌細胞の生 物学的悪性度を探る目的で flow cytometry を施行し
たところ, DNA index は1.5であり, DNA ヒストグラ ムは hyperdiploid type を呈し, S.phase fraction 21\%を占め，予想に反して，悪性度が比較的高いと思 われる結果を得た，しかし，再発までの30年という期 間を考虑すれば，初回手術時より癌細胞がこの状態に あったものとは考光難く，長期間いわゆる dormant cell の状態にあったものが，何らかの原因によってさ らに増殖性の強い細胞に変わり再発が明かになったも のと考えられた。

$$
\text { おわクに }
$$

乳蕉術後30年目に再発をきたした 1 例を経験したの で, DNA flow cytometryの結果すふまえて若干の文 献的考察を加え報告した。

$$
\text { 文嘀 }
$$

1）第 41 回乳癌研究会（フンタート調查）：日癌治療 会誌 $21: 1167,1986$

2) Thorud E, Fossa SD, Vaage S, et al: Priamry breast cancer-Flow cytometric DNA pattern in relation to clinical and histopathological characteristics-. Cancer $57: 808,1986$

3) Hedley DW, Rugg CA, Gelber RD: Association of DNA index and S-phase fraction with progmosis of nodes positive early breast cancer. Cancer Res $47: 4729,1987$

4) Dressler LG, Seamer LC, Owens MA, et al: DNA flow cytometry and prognostic factors in 1331 frozen breast cancer specimens. Cancer 61 : 
420,1988

5) von Rosen A, Rutqvist LE, Fallenius A, et al: Prognostic value of nuclear DNA content in breast cancer in relation to tumor size, nodal status, and estrogen receptor content. Breast Cancer Research Treatment $13: 23,1989$
6) van der Linden JC, Lindeman J, Baak JPA, et al: The multivariate prognostic index and nuclear DNA content are independent prognostic factors in priamry breast cancer patients. Cytometry $10: 56,1989$

\title{
A CASE OF BREAST CANCER RECURRED TO THE AXILLARY LYMPH NODE THIRTY YEARS AFTER OPERATION
}

\author{
Masatoshi OHTA, Takashi SUGIHARA, Masaya MUKAI, Tetsuji SASAKI and Kojiro SHIRAISHI \\ Department of Surgery, Tokai University, Tokyo Hospital \\ Yuko YANAGITA, Akira OKUMURA, Yutaka TOKUDA, Mitsuhiro KUBOTA, \\ Tomoo TAJMA and Toshio MITOMI \\ Second Department of Surgery, School of Medicine, Tokai University
}

A case of recurred breast cancer 30 years after operation for the primary breast cancer in a 73-year-old woman was experienced. In April 1960, the patient when she was 43 years old underwent modified radical mastectomy for a right breast cancer. In February 1990, the patient was admitted to the hospital because of a right axillary tumor. A $5 \times 4 \mathrm{~cm}$ unmovable and elastic hard mass was palpated, and serum NCC-ST-439 value was as high as $220 \mathrm{w} / \mathrm{ml}$. On April 4, 1990, lumpectomy was carried out. The excised tumor was $5 \times 4 \times 3 \mathrm{~cm}$ in size and solid. Histologically it was comprized of adenocarcinoma, accompanying by no lymph node tissues nor breast tissues. Immunohistologically $\alpha_{1}$-lactoalbumin, DF-3, 115D8, and NCC-ST-439 were positive. Estrogen receptor in the tumor tissues was positive due to $\mathrm{DCC}$ method. No probable primary lesions were found in the other organs clinically, accordingly the tumor was considered a metastasis of the breast cancer to the axillary lymph nodes. As of 11 months after excision of the axillary tumor followed by radiation to the axilla, there is no signs indicating recurrence and serum NCC-ST -439 is in normal range $(2.7 \mathrm{w} / \mathrm{ml})$. 